УДК 811.161.2’42:821.161.2-31.09Жадан

\title{
ПОЛІДИСКУРСИВНІСТЬ РОМАНУ СЕРГІЯ ЖАДАНА "ІНТЕРНАТ"
}

\section{Інна Онікіснко}

\author{
Криворізький державний педагогічний університет \\ Kryvyi Rih State Pedagogical University \\ пр. Гагаріна, 54, Кривий Ріг, 50086, Украӥна \\ onikienko69@gmail.com
}

Онікієнко І. Полідискурсивність роману Сергія Жадана "Інтернат"

У статті досліджено роль дискурсивних форматів роману для формування ідентичності людини. Зосереджено увагу на художній експлікації дискурсів радянського формату, мілітарному дискурсі насилля, антиімперському гуманістичному дискурсі, дискурсі індивідуальної свідомості, міфологічному дискурсі. 3'ясовано, що полідискурсивність постає як особливість свідомості кожної людини, яка може одночасно оперувати різними дискурсивними форматами. У цьому причина пошуків своєї самості та власної ідентичності, виражених також і в пошуках слова, що дешифрує прихований імперський дискурс, репрезентує нескомпрометовану ідеологією мову, уміння сказати правду самому собі.

Ключові слова: дискурс, полідискурсивність, ідентичність, другий модерн.

Оникиенко И. Полидискурсивность романа Сергея Жадана "Интернат"

В статье исследуется роль дискурсивных форматов романа для формирования идентичности человека. Акцентируется внимание на художественной экспликации дискурсов советского формата, милитарном дискурсе насилия, гуманистическом дискурсе, дискурсе индивидуального сознания, мифологическом дискурсе. Выясняется, что полидискурсивность является особенностью сознания каждого человека, которое может одновременно оперировать различными дискурсивными форматами. В этом причина поисков своей самости и собственной идентичности, выраженных также в поисках слова, которое расшифровывает скрытый дискурс империи, репрезентирует нескомпрометированный идеологией язык, умение сказать правду себе самому.

Ключевые слова: дискурс, полидискурсивность, идентичность, второй модерн.

Onikienko I. Poleidiscursiveness of the novel by Sergey Zhadan "Internat"

This article investigates the role of discursive novel formats for the formation of human identity. The focus is on the artistic explication of Soviet-style 
discourses, the militaristic discourse of violence, anti-imperial humanism, the discourse of individual consciousness, and mythological. It was found out that the polydiscursiveness in the novel by Sergei Zhadan "Internat" is due to the split consciousness of the hero of the novel. The author communicates the creation of an open artistic and psychological space by discussing the problems of national identity and modern statehood in Ukraine. The Soviet discursive format and the aggressive discourse of violence simulate imperial social reality, which is considered by the author as an inhumane social experiment on man and which can not be perceived in the modern democratic world. The author values human values in the process of deploying humanistic discourse, which represents the ideal social model and in which situationally realised responsible, courageous, heroic behaviour of man.

Since the discourse of violence provokes a mortal danger situation, the author also actively addresses the mythological discourse, in which the destabilising person is disfigured by a sense of fear and confusion. The discourse of individual consciousness, combined with the mythological, reflects the positive dynamics of Ithe character in the direction of identity. The complex interaction of the discourses of individual consciousness and social discourses leads to the nonlinearity of the text space, the shift of time coordinates, which allows to distinguish the philosophical existential discourse as a dominant, which determines the type of character consciousness and the relevance of the text to the literary examples of the era of the second modern.

Key words: discourse, polydiscursiveness, identity, second modernis.

\section{Постановка проблеми та іï зв'язок 3 важливими} науковими завданнями. Із 2014 року на території України російський агресор розгорнув гібридну війну на багатьох напрямках: соціально-ідеологічному, інформативному, психологічному. Представник інституту стратегічних досліджень А. Єрмолаєв констатує наявність у всьому світі “гібридизації міжнародних відносин, коли лінії конфліктності поступово переносяться зі сфери міжнародної у сферу політичної боротьби в середині окремих держав" [Yermolaiev / Срмолаєв 2015:6]. М. Требін у дослідженні стану України перед воєнними викликами сучасності стверджує: "Український прецедент лише підтвердив факт виникнення нової форми військового конфлікту, що починається 3 мирних антиурядових акцій і завершується жорстокою громадянською війною і зовнішньою інтервенцією” [Trebin / Требін 2014 : 247]. Зазначено, що жертвами конфлікту нового типу стають насамперед найбільш беззахисні категорії населення, а змістом військових дій у гібридній війні деморалізація і нав'язування своєї волі всьому населенню 
держави: “На полі бою з'являється безліч нових дійових осіб: формування бойовиків, кримінальні банди, міжнародні терористичні мережі, легіони іноземних найманців, підрозділи спецслужб різних країн світу” [Trebin / Требін 2014 : 249].

Аналіз останніх досліджень та публікацій. Виокремлені М. Требіним нові дійові особи сучасного життя України представлені в романі С. Жадана “Інтернат", вони втілюють дискурс насилля агресора. Зовнішні та внутрішні дискурси роману стосуються питання відновлення українською людиною втраченої Я-ідентичності й національної ідентичності, адже українська криза 2013-2014 років піднесла значення національної ідеї на чільне місце в житті держави й народу, який, як слушно зауважує А. Срмолаєв, у складній боротьбі "усвідомлює, що український прецедент може бути тиражований як спеціальна операція з руйнування державності” [Yermolaiev / Єрмолаєв 2015 : 21].

Проблема ідентичності актуалізувалася у філософських пошуках Нового часу. У постструктуралістській теорії Е. Лакло стверджується думка про фрагментарність суб' єкта: він виявляє множинність позицій у різних дискурсивних форматах. Оскільки суб' єкт постає як незавершена структура, то він прагне віднайти свою цілісність. І це може вдатися йому завдяки участі в різноманітних полеміках [Fillips / Филлипс 2008 : 81-83].

Актуальність дослідження зумовлена необхідністю окреслити дискурсивний вимір соціально-ідеологічних i психологічних феноменів у романі С. Жадана "Інтернат", які феномени сформувалися в “сірих зонах" - прифронтових територіях і територіях, захоплених бандформуваннями, де найбільше виявляється відчуження, яке має бути подолане задля національної єдності. Сучасні стани відчуження українців від України щойно стали предметом вивчення науковців та митців. Як почувається пересічна українська людина, маргінал, усвідомивши одного дня, що ії батьківська територія опинилася в ізоляції від решти Батьківщини і від усього світу й існує на умовах закладу закритого типу - інтернату? Якими шляхами можна йти до усвідомлення своєї Я-ідентичності? Як вийти із зони комфорту й почати відповідально ставитися до історії? 
Пошуки відповідей на ці складні запитання сучасності лягли в основу дискурсів роману С. Жадана “Інтернат".

Мета й завдання. Мета статті - визначення ролі дискурсивних форматів для формування ідентичності особистості. Мета зумовлює розв'язання таких завдань: 1) проаналізувати художні дискурси роману; 2) виявити їх боротьбу; 3 ) визначити динаміку персонажа в бік ідентичності.

Виклад основного матеріалу дослідження. У романі "Інтернат" автор протиставляє дві території, розділені внутрішніми лініями напруженості між зоною стабільності, де ще панує закон та міжнародне право, де пріоритетними є права людини, і територією невизначеності, яка характеризується зневагою до закону й права, мілітарним і психологічним насиллям. Відповідне розмежування отримують і дискурси роману. Інтернат - метафора на означення закритої зони, території відчуження і смертельної небезпеки, адже навколо нього й демонічно-містичного міста вже широко розгорнулися бойові дії. Із цієї території треба вийти та дійти до рідної станції, де ще немає боїв, де рідна домівка.

В інтерв’ю журналу “Апостроф”, від 13 серпня 2017 року С. Жадан так прокоментував соціальні й психологічні смисли віднайденої ним метафори: "Інтернат" - це не лише місце, де відбуваються події і де навчається один із персонажів. Це метафора неукоріненості, загубленості, невпорядкованості й неприкаяності. I це стосується багатьох із нас і країни загалом, тому що суспільство в нас теж страшенно не вкорінене в цю країну. Це невідчуття країни - такий певний синдром інтернату. Специфіка Донбасу - і в цій неукоріненості<... "” [Vasyliev / Васильєв 2017].

Чому в тексті роману відсутня історична конкретика i пряме називання міста Дебальцеве та станції Дебальцеве? На час написання роману 2015 року за станцію Дебальцеве йшли жорстокі бої, а на час виходу твору 2017 року українська армія вже втратила контроль над цим важливим об'єктом транспортної розв'язки. Операція “Дебальцеве” стала однією 3 трагічних сторінок російсько-української війни 2015 року. Саме психологічний стан загубленості й розгубленості блокує 
свідомість головного персонажа, не дає змоги визначитися в ситуації свій / чужий. Йому легше визнати цю війну чужою, тому в його мовному дискурсі відсутнє пряме називання агресора. Автор вдається до вказівних і відносних займенників, які вказують, але не називають когось, хто приховано бере участь у конфлікті: “вони”, “ті, хто”, “иі лише входять". У романі "Інтернат" спостерігаємо накладання й узаємодію кількох дискурсивних форматів. У творі дискурсивна неоднорідність отримує додаткову аргументацію: головний персонаж - Павло Іванович або просто Паша, учитель української мови звичайної дебальцівської школи, - змушений вийти із зони комфорту й, пересікаючи лінію фронту, дістатися школи-інтернату, розташованого на околиці міста Дебальцеве, у якому через хвороби серця й епілепсію перебуває його племінник. Уся подорож відбувається впродовж трьох днів і саме мотив дороги $є$ тут ключовим, як і в попередніх романах автора. У перший день Паша, який вдома навмисно ігнорував перегляд новин із телевізора, уже особисто зіштовхується 3 дискурсом насилля, що утверджувався засобами війни, агресії та нав'язуванням чужої символіки: “<..> зрозуміло було, щзо місто здадуть, щзо державні війська змушені будуть відійти, забравши з собою прапори" (4, с. 17). Мова військових розмежовує дискурси - загарбницький i державний - на блокпостах: “Мав би говорити державною <...>. Вони, не вони?" (4, с. 19).

Важливу роль у часово-просторовій організації роману відіграє переплетення реальних подій зі спогадами, які стають важливим способом реконструкції власної психобіографії й установлення Я-ідентичності головного персонажа. Павло Іванович не хотів визначатися зі своєю позицією щодо війни, удавав, що перебуває поза політикою. Він згадав, як чорний

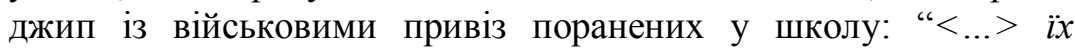
кладуть просто на підлогу між парт, а діти злякано переступають через свіжу кров" (4, с. 24). Розгубившись і не бажаючи нічого пояснювати дітям, учитель не знайшов нічого кращого, як залишити все на директорку й піти додому. Спогади поступово визначають зміст внутрішньої полеміки, яку 
провадить персонаж із самим собою. Цей внутрішній монологічний дискурс маркує його шлях не лише до інтернату, а й до власної ідентичності. Страшна дійсність війни вкупі зі спогадами актуалізують концепт “пам'ять”. Задуматися над необхідністю пам'ятати свою історію змусив Павла Івановича іноземний журналіст Пітер. Посеред воєнного хаосу він поводився упевнено, хоч і визнавав, що ситуація в Україні нагадує Середні віки: "Ніхто нічого не знає, ніхто нікому не довіряє" (4, с. 35). Пітер зауважує, що в Україні “історію вчити - як рибу ловити: ніколи не знаєш, що витягнеш" (4, с. 35). Іноземець похвалив українців за наполегливість докопуватися до правди. Його вустами автор виголошує одну з головних ідей свого роману: “Історія, знаєте, така штука $<\ldots$.. , яку ніхто не має права у вас відібрати?” (4, с. 36).

Iз попередніх творів С. Жадана знаємо, наскільки близьким його персонажам $є$ образ вокзалу, пов'язаний iз відчуттями власної невизначеності, загубленості, небажанням повертатися додому, бажанням небезпечних пригод. Можемо зауважити, як війна змінила і самого автора, й образний ряд його творів. Замість некерованого підлітка, зміст життя якого визначали мандри в нікуди, перед нами людина серйозної професії, що має своє обжите місце на землі, не бажає ні за яких обставин із ним розлучатися, майже патріот зі сформованим мовним самовизначенням. Однак з'ясовується, що мовне самовизначення в Павла Івановича існувало ніби саме по собі й не бажало зчіплюватися зі самовизначенням громадянським, що уподібнює його до фрагментарних суб'єктів попередніх романів автора. Жорстока воєнна дійсність змусила вчителя української мови, нейтрального громадянина, зробити крок до своєї цілісності. Цим кроком стала здатність до відповідальності. Спочатку Павлу Івановичу, який звик, що ні в школі, ні вдома ні за що не відповідає, довелося виводити з міського вокзалу до окружної дороги біженців. Він спостерігає, що тепер людей із різних соціальних груп робить схожими одне на одного страх: недовіра одне до одного, страх прийняти чиюсь допомогу. Мілітарний дискурс розгортається та набуває демонічномістичних ознак у метафоричному мовленні автора. Підвали 
будинків окупованого міста, у яких тижнями сидять люди, бо квартири повиривало вибухами, нагадують “братські могили" (4, с. 108). Спроба переночувати в балці завершується жахливою знахідкою пакетів з людськими тілами, від яких Паша біжить геть. За спиною в нього піднімаються зловіщі чорні повітряні змії обстрілюваного міста.

Антивоєнний дискурс С. Жадана, передусім, антиімперський за змістом, своєї кульмінації досягає в інтернаті під час дискусії Павла з директоркою Ніною. Разюче відрізняє Ніну від Павла почуття відповідальності за теперішне і майбутнє своїх учнів. Найкраще відчував цю різницю підліток Сашко і був ображений на дядька за його слабкодухість. Він вважав Пашу “мудаком" за те, що він "ні за кого". Коли Павло Іванович почув, як Ніна пояснює дітям, що "річ не в одязі, a y власній гідності. І відсутності страху” (4, с. 147], то зауважив, що ніколи не розмовляв зі своїми учнями на подібні теми. Ніна знаходилася зі своїми вихованцями в бомбосховищі, бо гранати залітали і до бібліотеки, i до спортзалу. Вона дбала про харчування, питну воду, виховувала дітей своїм прикладом. Коли двоє зривали прапор з інтернату, вона не дозволила, хоч сто осіб просто стояли і дивилися. На перший погляд, здавалося б, що такі діти, як Сашко, матимуть проблеми з адаптацією в суспільстві та 3 власною Я-ідентичністю через перебування в закритому середовищі. Сашко виступає в романі як центр, що організує всю родину до об'єднання. Своєю цілісністю й умінням самовизначатися хлопець завдячував передусім Ніні. Полеміка між учителями розгорнулася саме навколо відповідальності. На запитання Ніни “Ви зі своӥми дітьми про війну говорите?”, “А ви розумієте, щчо в половини з них батьки воюють проти нас?" Павло Іванович завчено висував свої аргументи: "Я мовник", "Я ні за кого", “Я не знаю, хто стріляе" (4, с. 159-160). Мовний дискурс суб'єкта ретранслює матрицю розмов місцевих жителів на території бойових дій та інформаційну політику гібридних воєн. Прихований дискурс суб'єкта видає його небажання або страх називати речі своїми іменами. Це уподібнює його позицію позиції ворога, що ховає шеврони і не виступає відкрито. Ніна намагається дешифрувати 
погану гру в необізнаність, наполягає на оприявленні у слові правди про ворога та його тактику: "Справдi? Спортзал виходить на південь і снаряд прилетів з півдня. А щуо в нас на півдні? Колишній державний кордон. I що тут не зрозумілого?" $(4$, c. 160$)$. Полеміка Ніни спрямована проти подвійних стандартів імперії й імперського мислення: “Давно слід було визначитися, з якого ви боку. Тому що ви теж усе бачили й усе знали. Але мовчали й не говорили" (4, с. 160).

Під час полеміки з'ясувалося, що фізрук Валєра та Павло Іванович ідеалізують своє совкове дитинство, відчувають за ним ностальгію. Ця ностальгія була прихованим дискурсом із незалежною Україною частини українських громадян, що мали проблеми з ідентичністю, отримала шанс реалізуватися в образі анархічних псевдореспублік, що реанімують імперські часи, упроваджуючи на окупованих територіях нові ганебні експерименти. Фізрук Валєра говорив казенною російською мовою, проте, за оцінками Паші, виявився “нормальним чуваком" (4, с. 142), бо захищав Ніну від місцевих покидьків, які увесь час прагнули здати ії в комендатуру. Із усіх учителів із Ніною залишився тільки він, решта - розбіглися. Фізрук ідеалізує середину 80 -х років, коли будували інтернат, а вони, підлітки, розкрадали будматеріали, бо іграшок ніяких не було. Їх навіть притягли до відповідальності, але вони не боялися, адже за ними була ціла країна. Фізрук співчуває інтернатським вихованцям: “Не в той час народилися, не в тій країні. Інша річ - ми. У нас була справжня країна, нам не треба було боятися. Я своє дитинство завжди згадую з усмішкою" (4, с. 156). Паша підтвердив, що й він згадує своє совкове дитинство з усмішкою. Проте знову лукавив, оскільки 3 дитинства виринав спогад про те, як батьки, зібравшись один раз за все життя на відпочинок, скасували його через брак коштів і він плакав, розбираючи свою маленьку валізу. Одна Ніна розказала правду про себе: “Мені їсти було нічого. У школі мене Спортсменкою називали, бо я завжди в кросівках ходила. Хтось із сусідів віддав <..> I мене ніхто не прикривав. I їх теж ніхто не прикриє. Крім нас з вами" (4, с. 157-158). Ніна протиставляє дискурсу насилля гуманістичний дискурс, де немає страху й кожна особистість 
наділена правом захищати свою гідність і свободу самовираження. Питання про безстрашність, героїзм та відповідальність дівчина розв'язує своїм власним прикладом.

Сьогодні твори С. Жадана сприяють формуванню відкритого громадянського суспільства, у якому всі атрибути радянської імперії $є$ неприйнятними. Фізрук Валєра експлікує в тексті роману радянський морально-етичний дискурсивний формат, зміст якого вказуе також і на формат економічнополітичний: розкрадання й кругова порука. Ніну, Сашка вирізняє неприйняття лицемірства як світоглядного компромісу, який, за визначенням Ю. Кушнерюка, “був головним елементом концепції радянської ментальності в чоловічій версії” [Kushneriuk / Кушнерюк 2008 : 141]. Полеміка між племінником і дядьком утілює версію конфлікту поколінь: посттоталітарного й того, що виросло під тиском колоніальних стандартів.

Пік психологічного напруження в романі, його кульмінація - смерть Ніни, яка своїм життям обороняла дітей від нападників. Із цього моменту все у свідомості Павла Івановича змінилося. У дискурсі суб'єкта з'являється нескомпрометована ідеологією мова, уміння сказати правду самому собі: "I саме тодi за деревами чітко ци прозоро проступає військова техніка - колона вантажівок, тягачів, танків, бронетранспортерів. Не поспішаючи, сунуть без кіния й початку. 3 півдня їдуть, ловить себе на думиі Паша. 3 боку державного кордону. Колишнього державного кордону<...>" (4, с. 171). Зміна дискурсів супроводжується переключенням дискурсивних ролей, які приймає на себе персонаж і, відповідно, зміною світоглядної позиції суб'єкта щодо дійсності. Помітивши, що свіжі сліди гусениць ведуть до інтернату, хлопці, не зговорюючись, побігли назад до корпусу. Вони дізналися, що мародери виносять з їдальні макарони, а фізрука Валєру порізали й завезли в госпіталь. Паша більше не думає про власну обережність і комфорт, а за будь-яку ціну хоче знайти Ніну. Першим віднайшов Сашко: "кілька кульових отворів у сукні", “затоптані газети з плямами вже застиглої крові” (4, с. 177). Свідомість Павла Івановича почала паморочитися. Спостерігаємо розщеплення свідомості 
головного персонажа між двома суб'єктами. Перший входить у повсякденний дискурс, відображає зміну Alter Ego персонажа від позиції конформіста, виробленої у школі й удома, до позиції небайдужого громадянина, що починає самовизначатися стосовно того, що відбувається. Друга іпостась суб'єкта позбавлена будь-яких соціально-ідеологічних нашарувань, повноваження якого розкрито у вагомому для роману просторі просторі міфу.

Міфологічний дискурс роману пов'язаний iз відображенням тих екзистенційно-містичних переживань суб'єкта, які викликає близька присутність смерті. Автор дає відчути поліфонію свідомості кожної людини. Філософія екзистенціалізму в поєднанні з міфомисленням дають підстави підстави кваліфікувати роман "Інтернат" як перший у сучасній українській літературі художній твір епохи другого модерну, що відображає страждання й життєву трагедію людини в зонах військової турбулентності, маркованих хаосом і нестабільністю. У зв'язку 3 цим А. Срмолаєв стверджує: “на наших очах народжується світ Нового Модерну - світ, обличчя і структура якого ще не визначені, а його народження відбувається не менш складно й суперечливо, як і знайомий нам світ Пізнього Модерну та Постмодерну довгого ХХ століття" [Yermolaiev / Єрмолаєв $2015: 3]$. Модернізм як складний комплекс літературно-мистецьких тенденцій на противагу натуралістичній практиці в художній дійсності “актуалізував інтуїтивізм, уводив принцип утаємничення у трансцендентну сутність буття" [Literaturoznavcha entsyklopediia / Літературознавча енциклопедія 2007 : 65].

С. Жадан поєднує відображення конкретно-історичних подій 3 інтерпретацією їх в екзистенційно-міфологічному просторі. У моменти небезпеки головний персонаж роману відчуває, як у профанний простір вступає сакральна присутність смерті. В. Войтович стверджує, що смерть - одне з основних уявлень міфологічної картини світу, вона символізує межу між "цим" і “тим" світом, водночас виступає важливою характеристикою “того” світу [Voitovych / Войтович 2002 : 487]. Трансцендентні можливості суб'єкта пов’язані 3 його 
спроможністю протистояти смерті, полемізувати 3 нею, попереджати іï появу. Ця здатність проявляється у виконанні певних дій, відшукуванні сакрального числа, що в ситуації смертельної небезпеки дорівнюють виконанню магічних ритуалів. Переживання Павлом Івановичем смерті Ніни викликало в нього відчуття межі, “ніби всередині в нього стискається пружина - велика, холодна, сталева <..> Стискається до кінця, до межі. Стискається, тиснучи на груди, не даючи дихати, перекриваючи повітря" (4, с. 178).

У художню тканину роману автор уводить культурноміфологічний код, пов'язаний із замовляннями та числобогом. В. Войтович визначає замовляння як “молитвослов магічного характеру, основою якого $є$ віра в чудодійну силу слова як засобу впливу на вищі духовні сили" [Voitovych / Войтович 2002 : 184]. У цьому разі суб'єкт роману демонструє віру в чудодійну силу сакрального числа. Він починає внутрішній зворотній відлік чисел від десяти до одного. Віднайдений спосіб подолання смерті виявляється дієвим і викликає відчуття, що "пружина різко розпрямляється, боляче витискаючи серце $<\ldots>$, кидаючи його назад, даючи йому сили рухатись далі" (4, с. 178). Магічне число десять пов'язує міфологічний дискурс С. Жадана із утвердженням життя й подоланням смерті, а також iз відновленням своєї втраченої цілісності, адже "десять священне число Всесвіту, бо має в собі всі інші числа. Це досконале число, бо означає повернення до цілісності. Символізуе Дерево життя, навколо якого за Сонцем водять хороводи" (4, с. 586). Позитивна динаміка у стосунках між дядьком і племінником свідчить про шлях головного персонажа до самовіднайдення. Смерть Ніни остаточно відновила психологічну довіру: “Тоді Пама міцно бере його за руку, так міцно, як тільки може. Малий охоплює його долоню, хапається за його мертві пальці, як за щзось, чому єдиному можна в ичьому житті довіряти, і вони рушають" (4, с. 182).

Доповнюють внутрішню полеміку суб'єкта зі смертю його дитячі спогади. У свої неповні п'ятнадцять років йому хотілося відкривати світ. У новорічну ніч, коли після довгої затримки ліг нарешті глибокий сніг, коли вдома всі заснули, хлопець пішов 
до ріки, потім по кризі дістався середини і раптом лід провалився, руйнуючи його натхнення та любов до світу. По пояс у крижаній воді він брів назад, а його переслідувала смерть у вигляді чорних крапок на сірому тлі. Долаючи владу смертельного холоду, він тікав від цих чорних крапок i врятувався, проте "цей зимовий присмак загибелі, крижане дихання страху та небуття будуть супроводжувати його до самої смерті, яка цьього разу промахнулась, проте навряд чи відмовилась від своїх прав" (4, с. 290).

Створюваний автором міф про подолання смерті разом із гуманістичним дискурсом і дискурсом індивідуальної свідомості протистоять світу обивателя - конформіста, який своєю байдужістю та відстороненістю підтримує тактику гібридної війни, нав'язувану агресором.

Насилля вселяє страх. Страх дає змогу здійснювати контроль над усіма членами суспільства. Паша зрозумів, чому Ніна навчала вихованців не боятися і сама не ховалася, захищаючи їх. У подоланні страху полягає героїзм, про який не думаєш, коли вчиняєш по совісті. Переконання у справедливості Ніниного виховання, у своєму праві на вільне життя робило сильним і Сашка. Дядько увесь час боявся, аби від пережитих потрясінь у хлопця не стався напад хвороби, але племінник уперто долав шлях додому, відігрівши та забравши 3 собою цуценя, яке теж мало право жити.

Дискурси роману сприяють обговоренню надважливої для сучасного українського державотворення проблеми: не стати сходу нашої держави територією, закритою для України та всього світу, - ось за що слід боротися українцям, які, як Павло Іванович, не мали змоги покинути свої домівки та виїхати із зони бойових дій. Окрім того, свідомість усіх українців мусить змінитися, як мусить змінитися й ставлення до Донбасу. Про своє бачення цієї проблеми С. Жадан розказав в інтерв’ю журналу “Апостроф”: “Це справді дивна і страшенно важлива річ, коли в місцевих змінюється усвідомлення себе, своєї країни, своєї батьківщини, коли змінюється усвідомлення свого патріотизму. Регіональний патріотизм треба долати. Батьківщина не обмежується кварталом <... >. Бо в нас часто 
украӥнець ховається за свій хутір, свою вулищую. I насправді така доволі зручна позиџія дає можливість тобі усунутися від прочесів, які відбуваються з краӥною" [Vasyliev / Васильєв 2017]. Тому дуже вчасно і справедливо, що у 2017 році С. Жадан став лауреатом премії ім. В. Стуса "за особливий внесок в українську культуру та стійкість громадянської позиції”.

Висновки та перспективи подальших наукових розвідок. Полідискурсивність у романі С. Жадана "Інтернат" зумовлена розщепленістю свідомості героя роману. Установка автора - створення відкритого художньо-психологічного простору для обговорення проблем національної ідентичності йсучасного державотворення в Україні. Радянський дискурсивний формат i загарбницький дискурс насилля моделюють імперську соціальну реальність, яка розглядається як антигуманний соціальний експеримент над людиною і яка не може бути сприйнята в сучасному демократичному світі.

Загальнолюдські цінності обстоюються у процесі розгортання гуманістичного дискурсу, що репрезентує ідеальну соціальну модель і в якому ситуативно реалізується відповідальна, мужня, героїчна поведінка людини. Автор активно звертається й до міфологічного дискурсу, у процесі якого знешкоджуються дестабілізуючі людину почуття страху й розгубленості. Дискурс індивідуальної свідомості, поєднавшись iз міфологічним, відображає позитивну динаміку Я-персонажа в напрямку ідентичності.

Складна взаємодія дискурсів індивідуальної свідомості й соціальних дискурсів спричиняе нелінійність текстового простору, зміщення часових координат, що дає змогу виокремити філософський екзистенційний дискурс як домінантний, що визначає тип свідомості персонажа та належність тексту до літературних зразків епохи другого модерну. Полідискурсивність постає як особливість свідомості кожної людини, яка може одночасно оперувати різними дискурсивними форматами. У цьому причина пошуків своєї самості та власної ідентичності , виражених також і в пошуках слова, що дешифрує прихований імперський дискурс, оприявлює нескомпрометовану ідеологією мову, уміння сказати правду самому собі. 


\section{Література}

1. Васильєв С. Інтерв”ю Сергія Жадана журналу “Апостроф” від 13 серпня 2017 року. URL : https: //apostrophe.ua > society > culture.

2. Войтович В. Українська міфологія. Київ : Либідь, 2002. 664 с.

3. Єрмолаєв А., Денисенко С. Маркєєва О., Поляков Л. Український конфлікт і майбутне світової та європейської безпеки. Нова Україна. Iнститут стратегічних досліджень. Київ, 2015. 30 c. URL: http.: // newukraineinstitute.org / media / news /501 / file / crisis security \% 20UKR pdf.

4. Жадан С. Інтернат : роман. Чернівці : Меридіан Черновіц, 2017. 336 с.

5. Кушнерюк Ю. Концепція радянської ментальності в українській молодіжній прозі початку XXI ст. Вісник Запорізького наиіонального ун-ту. Серія : Філологічні науки. 2008. № 2. С. 138-142.

6. Літературознавча енциклопедія : у 2-х томах / авт.-уклад. Ю. І. Ковалів. Київ : ВЦ “Академія“, 2007. Т. 2. 624 с.

7. Требін М. Україна перед воєнними викликами сучасності. Вісник Національного ун-ту "Юридична академія Украӥни ім. Ярослава Мудрого". Серія : Філософія, філософія права, політологія, соиіологія. 2014. № 4 (23). C. 246-251.

8. Филлипс Л., Йоргенсен М. В. Дискурс-анализ. Теория и метод. 2-е изд., испр. Харків : Гуманитарный Центр, 2008. 352 с.

\section{References}

1. Vasyliev S. Interviu Serhiia Zhadana zhurnalu "Apostrof" vid 13 serpnia 2017 roku. URL : https: //apostrophe.ua > society > culture.

2. Voitovych V. Ukrainska mifolohiia. Kyiv : Lybid, 2002. $664 \mathrm{~s}$.

3. Yermolaiev A., Denysenko S. Markieieva O., Poliakov L. Ukrainskyi konflikt i maibutnie svitovoi ta yevropeiskoi bezpeky. Nova Ukraina. Instytut stratehichnykh doslidzhen. Kyiv, 2015. 30 s. URL : http.: // newukraineinstitute.org / media / news 1501 / file / crisis_security \% 20UKR pdf.

4. Zhadan S. Internat : roman. Chernivtsi : Merydian Chernovits, 2017. $336 \mathrm{~s}$.

5. Kushneriuk Yu. Kontseptsiia radianskoi mentalnosti v ukrainskii molodizhnii prozi pochatku XXI st. Visnyk Zaporizkoho natsionalnoho un-tu. Seriia : Filolohichni nauky. 2008. № 2. S. 138-142.

6. Literaturoznavcha entsyklopediia : u 2-kh tomakh / avt.-uklad. Yu. I. Kovaliv. Kyiv : VTs "Akademiia“, 2007. T. 2. 624 s.

7. Trebin M. Ukraina pered voiennymy vyklykamy suchasnosti. Visnyk Natsionalnoho un-tu "Iurydychna akademiia Ukrainy im. Yaroslava Mudroho". Seriia : Filosofiia, filosofiia prava, politolohiia, sotsiolohiia. 2014. № 4 (23). S. 246-251.

8. Phillips L., Jorgensen M. V. Discourse analysis. Theory and method. 2 nd ed., Corr. Kharkiv : Humanitarian Center, 2008. 352 p.

Стаття надійшла до редакиії 22.02.2019 p. Прийнята до друку 07.05.2019 p. 